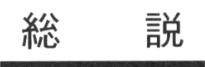

\title{
植物エストロゲンとその核内レセプター
}

\author{
金子 秀雄
}

住友化学工業株式会社 生物環境科学研究所

（干554-8558 大阪市此花区春日出中 3-1-98)

\section{Phytoestrogens and Their Nuclear Receptors}

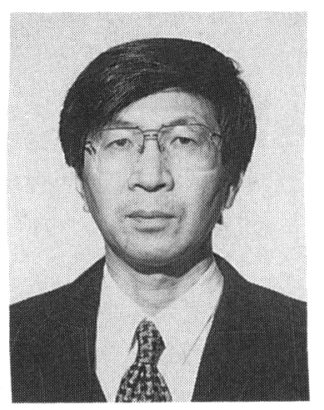

\author{
Hideo Kaneko
}

Sumitomo Chemical Co., Ltd., Environmental Health Science Laboratory

(3-1-98, Kasugade-Naka, Konohana-ku, Osaka 554-8558)

\begin{abstract}
About 200 natural substances are known to be phytoestrogens which are derived from plants with estrogenicity. Among them, isoflavones are the most potent, and coumestrol, genistein and daidzein show greater estrogenicity than other phytoestrogens. Estrogenicity of phytoestrogens is discussed in terms of endocrine disruption, since Japanese consume large quantities of phytoestrogens present in soy products, apparently having greater estrogenicity (in vitro assay) and daily intake as compared with general chemicals (such as Bisphenol A or 4nonylphenol) frequently cited as estrogenic compounds. On the other hand, isoflavones are considered effective for preventing osteoporosis, breast cancer and prostate cancer and reducing blood cholesterol. The mode of action of phytoestrogens on the molecular level should be clarified so as to estimate risks and benefits of phytoestrogens.
\end{abstract}

Key words : phytoestrogen, estrogen receptor $\alpha \& \beta$, isoflavones

\section{1 はじめに}

最近，人口の高齢化抢よび健康意識の高揚に伴い，植 物由来化合物の薬効に関心が集まっている。特に, 女性 にとっては閉経後の骨粗鬆症の発症は生活の質に係わり 重大な関心事であり，その䂆方薬としてイソフラボン類 が有効とのことで，実際に商品として利用されている。 また，日本人を含むアジア人と西洋人との間では乳がん や前立腺がんの発症に人種差があり, それが食物として 㠌取する植物エストロゲンに由来しているという報告も ある ${ }^{1)}$ 3)。一方, 一昨年来, 化学物質の内分泌摫乱作用 が社会問題化している。それはコルボーン博士の著書

(Our Stolen Future: 邦題：奪われし未来) の刊行が 引き金となっている。同著書の中でフロリダ州アポプカ 湖でのワニの生殖器の短小化が例としてあげられ, また, 日本近海でのイボニシの雌雄同体, また, 昨年, 新聞紙 上で日本成人男子の精子の質・量についての報告がマス コミ等で広く伝えられた。この主原因は, 化学物質の内 分泌系, 特に性ホルモン系の筧乱作用ではないかと推測 されているが，現在まだ十分には解明されていなく，日
本, 米国および OECDにおいてその検出方法または試 験方法を検証中である。

一方, bisphenol-A および 4-nonylphenol 等の一般化 学物質の一部について, それらの女性ホルモン様作用の ために内分泌擋乱作用があるのではないかと繁念がもた れている。しかし, 現実には日本人は大豆由来食品を日々 撕取することにより植物由来の女性ホルモン様化合物を 大量に摂取している。現在，極微量でしか摂取せず，か つ弱い女性ホルモン様作用を示す合成化学物質だけがお もに問題にされているが, 食品を通じて摂取する植物エ ストロゲンも含めて考えるべきとの議論がある。

本稿では植物エストロゲンについて, そのホルモン作 用検出方法抢よびその結果について概説する。

\section{2 ホルモンの情報伝達(4) 7)}

ホルモンの生体内での情報伝達は, 特定の器官・臓器 で産出され，血液中をタンパク質と結合して運搬され， 標的組織でレセプターに結合し, 標的細胞内でホルモン 情報が遺伝子にまで伝達され種々のホルモン応答が起き る。ホルモンには水溶性ホルモン (ペプチド, タンパク 
等) と脂溶性ホルモン (ステロイドホルモン等) があり， 一般的に，水溶性ホルモンは細胞膜を透過できないため に細胞膜上にレセプターが存在して, 反対に脂溶性ホル モンは細胞質もしくは核内にレセプターが存在する。女 性ホルモン扣よび男性ホルモン等のステロイドホルモン は細胞質もしくは核内に存在するレセプターに結合す る。

\section{$2 \cdot 1$ 性ホルモンの生合成経路}

男性ホルモン，女性ホルモン，副腎皮質ホルモン等の ステロイドホルモンはすべてコレステロールより生合成 される。即ち, コレステロールの側鎖切断により生成す る pregnenolone から, さらに数種の P 450 酵素 (CYP $11, \mathrm{CYP} 21$ 等) による水酸化および脱水素反応により 男性ホルモンである testosteroneが合成される。 testosterone はさらにアロマターゼ（CYP 19）により女性ホ ルモンである estradiolに，また testosterone は $5 \alpha-リ$ ダクターゼにより活性体の dihydrotestosterone に変換 される。このように生合成された性ホルモンはステロイ ド結合タンパクと結合して血液中を標的器官へ運搬さ れ，レセプターと結合してその化学情報は伝搬される。

女性ホルモンは主として卵巣 (卵胞, 黄体), 胎盤な どで産出されるが, 脂肪組織, 副腎, 精巣でも少量であ るが産出される6)。

\section{$2 \cdot 2$ 性ホルモンレセプター}

$2 \cdot 2 \cdot 1$ 性ホルモンレセプターについて

女性（エストロゲン）および男性（アンドロゲン）ホ ルモンレセプターは他のステロイドホルモン（副腎皮質 ホルモン等), ビタミン $\mathrm{A}$, ビタミン $\mathrm{D}$, 甲状腺ホルモ ンレセプターと同様に細胞質もしくは核分画に存在し， また，共通構造（スパーファミリーを形成）を有してい る。共通の基本構造は，レセプターの中央に亜鉛を含む DNA 結合領域（ジンクフィンガー）を有し，C末端領 域にはホルモン結合領域を有する。 $\mathrm{N}$ 末端および $\mathrm{C}$ 末 端領域には転写活性に関連している7 (Fig. 1)。現在で
は, このレセプター群に属しているレセプターは, 本来 のリガンドが未知のもの（オーファンレセプター）も含 めると約 60 種が知られている。エストロゲンまたはア ンドロゲンレセプターの DNA 結合様式は DNA の特異 配列（AGGTCA）に数塩基対を隔てて，反対方向の結 合する(逆位反復配列：パリンドローム)。一方, 甲状

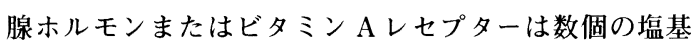
対を隔てて同方向（反復配列：ダイレクトリピート）に 結合する ${ }^{7) .8) 。 ~}$

エストロゲンレセプターの遺伝子配列は 1980 年代の 中ごろに解明され，それ以降多くの研究がなされたが， 1996 年に驚くべき報告がなされた。それは，これまで エストロゲンレセプターは一つと考元られてきたが，も うひとつのエストロゲンホルモンレセプターが報告され た6)。先に報告されたエストロゲンレセプターを $\alpha$ と, また，後で発見されたレセプターを $\beta$ と呼ばれている。 構造的には両レセプターの DNA 結合領域の相同性は $90 \%$ 以上でホルモン結合領域は $58 \%$ の相同性であった

(Fig. 1)。現在，この 2 種のレセプターの組織分布の 違い, 機能の違いについて検討されている。即ち, この 2 種のエストロゲンレセプターの体内での発現は非常に 異なっていることが判明した。 $\beta$ が最も多く発現してい るところは卵巣と前立腺, 中程度が睪丸, 子宮, 膀腅, 肺で, 下垂体, 副睪丸, 胸腺, 脳は低い発現量を示した。 一方， $\alpha$ は睪丸（打よび副睪丸）, 下垂体, 子宮, 腎臓, 副腎でこれらの臓器では $\beta$ は弱い発現か全く認められ ていない。脳は全般的に $\beta$ が分布し， $\alpha$ はほとんど認め られなかった。卵巣打よび子宮は両レセプターが発現し ていた ${ }^{6) .9) 。 ~}$

\section{$2 \cdot 2 \cdot 2$ レセプターと化学物質の結合性 ${ }^{4) .5}$}

レセプターと化学物質の結合性には 2 種類ある。それ らは, 化学物質がレセプターと結合してホルモン様作用 を示す場合（ホルモン作動性：アゴニスト活性）とホル モンがレセプターに結合することを阻害する場合（ホル

Domains of Nuclear Receptor Superfamily

\begin{tabular}{|l|l|l|l|l|}
\hline $\mathrm{A} / \mathrm{B}$ & $\mathrm{C}$ & $\mathrm{D}$ & $\mathrm{E}$ & $\mathrm{F}$ \\
\hline
\end{tabular}

\footnotetext{
Primary function of each domain

$\mathrm{A} / \mathrm{B}$ : Activation function-1

C : DNA binding domain (Zn finger) , Dimerization

$\mathrm{E}$ : Ligand binding domain, Activation function-2、Hsp90 binding
}

Estrogen receptor $\alpha \& \beta$

Estrogen receptor $\alpha \& \beta$
\begin{tabular}{|c|c|c|c|c|}
\hline $\mathrm{A} / \mathrm{B}$ & $\mathrm{C}$ & $\mathrm{D}$ & $\mathrm{E}$ & $\mathrm{F}$ \\
\hline $16.5 \%$ & $95.5 \%$ & $28.9 \%$ & $58.5 \%$ & \\
\hline $\mathrm{A} / \mathrm{B}$ & $\mathrm{C}$ & $\mathrm{D}$ & $\mathrm{F}$ & $\mathrm{F}$ \\
\hline
\end{tabular}

Fig. 1 Structural Domains of Nuclear Receptor Superfamily and Comparison of Estrogen Receptor $(\alpha \& \beta)$. 
モン作動阻害性：アンタゴニスト活性）である。例えば， 女性ホルモンレセプターのアゴニストには，合成女性ホ ルモン (ethinylestradiol), DES (diethylstilbestrol) がある。アンタゴニストとしては乳がん治療薬のタモキ シフェンが良く知られている。しかし，アンタゴニスト およびアゴニストは絶対的なものでなく，細胞により異 なることが知られている10)。

\section{3 試験方法}

\section{$3 \cdot 1$ in vitro レセプターアッセイ法 ${ }^{4) .5)}$}

性ホルモンレセプターに対する化学物質の結合性を調 ベる方法には，大きく 3 種類あり，それらはレセプター と化学物質の結合性を調べる方法 (バインディングアッ セイ), レセプターの転写活性を指標とする方法 (レポー タージーンアッセイ）および細胞增殖性アッセイ法があ る。各々のアッセイ法について以下に概説する。

$3 \cdot 1 \cdot 1 \quad$ バインディングアッセイ

バインディングアッセイとはレセプターに放射性もし くは蛍光を有する天然のホルモンリガンドと被験化合物 との競合結合性から，被験化合物のレセプターに対する 結合の強さを知る方法である。バインディングアッセイ の検出感度は高いものの, アンタゴニストとアゴニスト の区別ができない欠点がある。

$3 \cdot 1 \cdot 2$ 細胞增殖性アッセイ

ホルモンレセプターに対する作用性を調べる方法とし て, E-screen と呼ばれているものでヒト乳がん由来細 胞 MCF-7 が女性ホルモン量に依存して細胞增殖が促進 されるということを原理とする方法である。しかしなが ら，MCF-7 の增殖は必ずしもエストロゲン作用だけに 依存するのではなく, 種々の増殖因子によっても増殖す る。

$3 \cdot 1 \cdot 3$ 転写活性を指標としたアッセイ系(レポーター ジーンアッセイ)

培養細胞もしくは醉母に性ホルモンレセプター遺伝子 とレポーターと呼ばれる遺伝子を遺伝子工学的手法によ り細胞に同時に導入する。一般的にはレポータ一遺伝子 にはクロラムフェニコールアセチラーゼかルシフェラー ゼが選ばれる。このアッセイの原理は, 細胞内で発現し たレセプターにホルモンが結合すると，レポーター遺伝 子の上流にある応答配列に結合して下流にあるレポー ター遺伝子の転写活性化を増大させてレポーター䤃素が 増える。その酵素活性を測定することによりレセプター と化学物質との結合を知ることができる。醉母を用いた 場合の特色としては, 培養細胞で見られたようなアンタ ゴニスト抢よびアゴニストの区別が出来ないことと, 醅 母には細胞壁があり化学物質の透過性が悪く, 感度が若 干低下する欠点がある。

$3 \cdot 2$ in vivo 試験法 ${ }^{5}$ ?
化学物質の女性ホルモン様作用検出のための生きた動 物を用いる試験方法は数種存在するが, 最も良く知られ ている方法は子宮增殖性試験である。即ち, 卵巣摘出ラッ 卜もしくは未成熟ラットに化学物質を投与後に子宮重量 を中心として女性ホルモン量に依存的に変化するパラ メーターを測定する。アゴニストを測定する際には試験 群には被験化合物だけを投与し，対照群には溶媒だけを 投与して子宮重量を比較検討する。一方，アンタゴニス トの活性測定する場合は，試験群では estradiol と被験 化合物を同時投与し，対照群では estradiol だけを投与 して，子宮重量を比較検討する。参考までに記すと，男 性ホルモン様化合物検出法は Hershberger 試験（前立 腺アッセイ）と知られていて，雄ラットを去勢後に化学 物質を投与し，前立腺重量を中心にして男性ホルモン依 存的に変化するパラメーターを測定する。

\section{4 植物由来女性ホルモン様化合物の分布 ${ }^{1) ~ 31}$}

植物由来のエストロゲン様活性を示す化合物は現在約 200 種類知られている。それらを総称して植物エストロ ゲン (phytoestrogen) と称されている。植物エストロ ゲンのよく知られている例は，オーストラリアでクロー バーを食べた羊に妊娠異常が起きたことである。これは イソフラボンの formononetin 大量に含んでいたク ローバーを食べ，equol が体内で生成したためである。 このことは植物が草食動物から身を守るためにこのよう な化合物を産生しているという説もある。植物エストロ ゲンには，構造的にはフラボノイド類（フラボン類，イ ソフラボン類）执よびリグナン類である。また，微生物 の産出物である mycoestrogen がある。イソフラボノイ ド類は大きく 3 種類に分かれ，それらは，イソフラボン 類, イソフラバン類, クメスタン類に分かれる (Fig. 2)。 イソフラボン類はリグナン類ほど植物に広く分布せず, マメ科を中心に，特に大豆に多く含まれている。Table 1 に種々の植物エストロゲンが含まれている植物打よび 食品を示す2)。また, Table 2 に大豆製品を中心にイソ フラボン類の genistein, daidzein および coumestrol の 含量を示す。Table 2 より，大豆製品の中でも黄粉およ び大豆タンパクに genistein および daidzein が多く含ま れていることがわかる。一方，リグナン類は薬用植物の 有効成分として知られている。哺乳動物で見いだされる リグナン類 (enterolactone, enterodiol) は穀物, 種か ら腸内細菌により変換を受けたもので，植物りグナンで ある matairesinol および secoisolariciresinol とは異なる

(Fig. 2)。

5 植物由来エストロゲン類の 女性ホルモン様活性

エストロゲンレセプターに対する結合性は, アッセイ 
Table 1 Natural Estrogens and Their Sources ${ }^{2)}$.

\begin{tabular}{ll}
$\begin{array}{l}\text { Natural Estrogens } \\
\text { or Plants }\end{array}$ & \multicolumn{1}{c}{ Sources or estrogenic acitivity } \\
\hline $\begin{array}{l}\text { Coumestrol } \\
\text { Zearalenone }\end{array}$ & $\begin{array}{l}\text { sunflower, alfalfa, legumes, soybean products } \\
\text { cereals, wheat, barley, oats, produced by molds } \\
\text { Zearalanol }\end{array}$ \\
metabolite of zearalenone \\
barley, oats, rye, rice, wheat, soybean products, beer \\
Daidzein & barley, oats, rye, rice, wheat, soybean products, beer \\
Equol & soybean products \\
Biochain A & alcohol beverages (bourbon) \\
$\beta$-Sitosterol & alcohol beverages (bourbon) \\
Apple/Cherry/plum & weakly estrogenic \\
Potato & weakly estrogenic \\
Rhubarb & weakly estrogenic \\
Beets & weakly estrogenic \\
Parsley & weakly estrogenic \\
Coffee & weakly estrogenic \\
Garlic & weakly estrogenic \\
\hline
\end{tabular}

Isoflavonoids

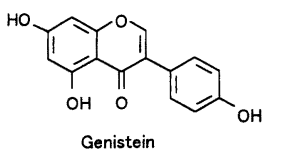<smiles>O=c1oc2cc(O)ccc2c2oc3cc(O)ccc3c12</smiles>

Lignans

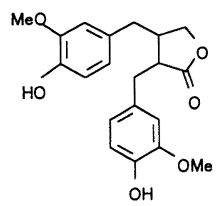

Matairesinol<smiles>O=C1OCC(Cc2cccc(O)c2)C1Cc1cccc(O)c1</smiles>

Enterolactone
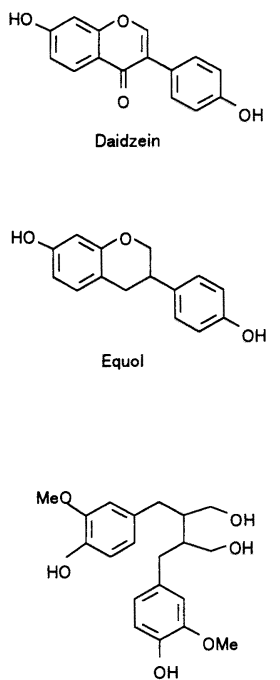

Secoisolariciresinol

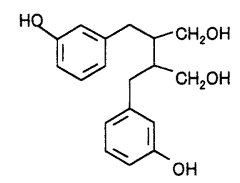

Enterodiol

Fig. 2 Chemical Structures of Phytoestrogens.

方法によりその強度がかなり異なるが，フラボノイド類 およびリグナン類の中で最も高い結合性を示すのはイソ フラボン類で, その中でも coumestrol が一番活性が高 いと考える。Table 3 に酵母を用いたレポータージーン

Table 2 Isoflavone Contents of Various Foods ${ }^{1,3)}$.

\begin{tabular}{lrrr}
\hline \multicolumn{1}{c}{ Foods } & Genistein & \multicolumn{2}{c}{ Daidzein Coumestrol } \\
\hline Alfalfa & & & \\
$\quad$ sprout & ND & ND & 47 \\
Garlic & 1 & 2 & NA \\
Carrots & 2 & 2 & NA \\
Soybeans & & & \\
$\quad$ dry, whole & 200 & 700 & ND \\
soy flour & 850 & 520 & ND \\
sprouts & 230 & 140 & 7 \\
$\quad$ soy protein & 640 & 520 & ND \\
Soy bean products & & & \\
$\quad$ tofu & 170 & 76 & ND \\
soy sauce & 5 & 8 & ND \\
soy milk & 26 & 18 & ND \\
miso & 380 & 270 & NA \\
\hline
\end{tabular}

Unit : ug/g ND : not detected, NA : not analyzed These data are from literatures 1 and 3

アッセイの種々の化合物とイソフラボン類を含む植物エ ストロゲンの結果を示す ${ }^{11)}$ 。Table 3 より植物エストロ ゲン中でも coumestrolが最も強く, equol, genistein お よび daidzeinも比較的強い活性を示す。これらの活性 は内分泌擋乱作用で問題となった bisphenol Aおよび 4-nonylphenol より約 10 倍以上強く,この結果について は, 我々のヒト子宮がん由来 HeLa 細胞を用いたレポー タージーンアッセイでも同様な結果を得ている ${ }^{22}$ 。また, イソフラボン類は古くから問題視されている $o^{\prime}, p^{\prime}-$ DDT より数析高い強さを示す。穀物類に寄生する微生 物の産物である zearalenone および関連化合物にも強い エストロゲン活性がある。一方，フラボン類はイソフラ ボン類よりも全般的にエストロゲン様活性は低いが，レ ポータージーンアッセイでは apigenin, naringenin, 
Table 3 Estrogenicity of Phytoestrogens and Chemicals by Yeast Reporter Gene Assay ${ }^{11}$.

\begin{tabular}{lc}
\hline \multicolumn{1}{c}{ Chemicals } & Relative activity \\
\hline Natural estrogens & \\
$17 \beta$-Estradiol & 100 \\
Synthetic estrogens & \\
$17 \alpha$-Ethynylestradiol & 89 \\
Diethylstilbestrol & 74 \\
Triphenylethylene antiestrogens & \\
Tamoxifen & 0.0047 \\
4-Hydroxytamoxifen & 0.0073 \\
Steroids & \\
Cholesterol & 0 \\
Androstenedione & 0 \\
Testosterone & 0.001 \\
Progesterone & 0 \\
Phytoestrogens & \\
Coumestrol & 0.67 \\
Equol & 0.085 \\
Daidzein & 0.0013 \\
Formononetin & 0.0056 \\
Bochanin A & 0.0091 \\
Genistein & 0.049 \\
Mycoestrogens & \\
Zearalenone & 0.26 \\
$\alpha-$ Zearalanol & 8.7 \\
Pesticides & \\
$o ', p$ '-DDT & 0.00011 \\
Methoxychlor & 0.0033 \\
4-Alkylphenols & 0.005 \\
4-Nonylphenol & 0.003 \\
4-Octylphenol & 0.005 \\
Other contaminants & 0.0004 \\
Bisphenol A & \\
Di- $n$-butylphthalate & \\
Butylbenzylphthalate & \\
\hline &
\end{tabular}

kaempferol は比較的強いエストロゲン様活性を示す。 一方, chrysin, fisetin および quercetin はほとんど活性 を示さない ${ }^{13)}$ 。

Coumesterol をマウスまたはラットに投与すると臸開 口, 臸の角質化, 子宮重量の増加等のエストロゲン作用 を示す。Table 4 に示すように上述のレポータージーン アッセイの結果と同様にin vivoでの子宮增殖性アッセ イ法でも coumestrol は bisphenol A や 4-nonylphenol よ り強い活性を有す。尚，イソフラボン類はエストロゲン レセプターに対してほとんどがアゴニストとして作用す るが，時によってはアンタゴニスト作用があると報告さ れ，一致した見解はない》。

イソフラボン類のエストロゲンレセプター $\alpha$ および $\beta$ に対する結合性を検討したところ，エストロゲンレセプ ター $\alpha$ より $\beta$ に対して高い結合性を示す。このイソフ
Table 4 Relative Uterotrophic Potency of Natural Estrogens, Phytoestrogens and Other Chemicals $^{11)}$.

\begin{tabular}{cc}
\hline Chemicals & Relative activity \\
\hline Natural estrogens & 100 \\
$17 \beta$-Estradiol & \\
Synthetic estrogens & 234 \\
Diethylstilbestrol & \\
Phytoestrogens & 0.024 \\
Coumestrol & \\
Mycoestrogens & 0.026 \\
$\alpha$-Zearalanol & \\
4-Alkylphenol & 0.00036 \\
4-Nonylphenol & 0 \\
4-Octylphenol & \\
Other contaminants & 0 \\
Bisphenol A & 0 \\
Butylbenzylphthalate &
\end{tabular}

ラボン類のエストロゲンレセプターに対する選択性の意 味は今後の検討課題と考える ${ }^{1)}$.9)。

\section{6 植物エストロゲンのヒトへの影響 一疫学検討 ${ }^{11.22}$}

大豆撕取により動脈硬化の進行が防げることがここ 50 年の研究によって明らかになってきているがその原 因が明確ではなかったが，最近その原因はイソフラボン 類がその作用の元であることが明らかになってきた。イ ソフラボン類の投与によりサルにおいて，子宮に影響を 与えずに血清中のコレステロール低下作用等の脂質改善 の結果が得られつつあり, 閉経後のホルモン補充療法で イソフラボン類が有効であることが期待できる。

疫学的調査より, 西洋人より日本人および中国人では 乳がん, 大腸がんおよび前立腺がんの発症頻度が低いの は大豆の摄取によると考えられている。多くの疫学調查 より, 大豆の掑取は乳がん, 前立腺がん, 循環器系疾患 の発生頻度低下, 閉経後の更年期障害症状の軽减, 骨粗 鬆症の発生の低下に有効との結果がある。大豆の摂取が ヒトでエストロゲン作用を示すかどうかを調べるため に, 閉経後の 97 人女性に大豆（genistein 抢よび daidzein）を 4 週間椇食させエストロゲン作用をいろい ろな角度から調べたところ, 胵上皮細胞にその弱い作用 性を見いだされる。また, バーボンウイスキーの主要植 物エストロゲンである $\beta$-sitosterol および biochanin A を 4 人の閉経後の女性に投与し，エストロゲン作用を調 ベたところその作用が見いだされた。酒類中の植物エス トロゲンは, 肝硬変等の肝蔵の機能低下を示しているヒ トではエストロゲン作用を示す可能性がある。ビールに は genistein および daizein が含まれていて, in vitro で エストロゲンレセプターへの結合性を調べたところ, 
Table 5 Racial Differences in the Amount of Urinary Phytoestrogens and Natural Estrogens ${ }^{15)}$.

\begin{tabular}{l|c|c|c}
\hline $\begin{array}{c}\text { Urinary estrogens } \\
\text { or phytoestrogens }\end{array}$ & Japanese/Oriental & American & Finnish \\
\hline Genistein & 3400 & & 32 \\
Daidzein & 2600 & 220 & 41 \\
Equol & 2600 & 63 & 44 \\
$17 \beta$-Estradiol & 0.76 & & 0.94 \\
(Postmenopausal) & & & \\
\hline
\end{tabular}

Unit : nmol/24hr

ビールはバーボンウイスキーよりも結合性は強いことが 判明した。さらに，閉経後の日本女性は“Hot Flush” の発症が西洋人に比べて著しく低いのは，エストロゲン 作用を有する植物エストロゲンの撕取に関連していると 考えられる。そこで，日本人，アメリカ人およびフィン ランド人の尿中のイソフラボン類量を測定したところ， 日本人はアメリカ人およびフィンランド人に比べて, 著 しく高濃度のイソフラボン類を排泄していることが判明 した ${ }^{14)}$ 。これは大豆製品（豆腐, 味骝, 油揚げ, 厚揚げ, 高野豆腐）の摂取に起因すると考えられている（Table 5 )。また，男性の前立腺がんの低い死亡率は低脂肪食 と大豆製品の椇食によると考えられ, 日本人男性とフィ ンランド人の血中 daidzein, genistein および equol の遊 離体および硫酸もしくはグルクロナイド抱合体の量を比 較したところ，約 7〜50 倍日本人の方が高いことが判明 した15)。

\section{7 植物由来エストロゲン類の種々の薬理作用}

植物エストロゲンはエストロゲンレセプターに関連す ることなくチロシンキナーゼ阻害, トポイソメラーゼ阻 害, アロマターゼ阻害, 血管新生阻害を示すとの報告が ある。特にチロシンキナーゼおよび血管新生作用は発が ん性に関連しており，大豆製品の摂食は発がんの予防に

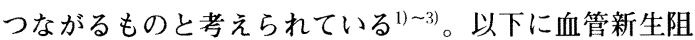
害およびアロマターゼ阻害について若干説明する。

\section{$7 \cdot 1$ 血管新生阻害 ${ }^{16)}$}

固形がんの増殖をはじめとする多くの病気に血管の内 皮細胞の増殖が関係しているが，ヒトの尿中にそれを阻 害する物質が存在することが知られているがその物質を 抽出・構造決定したところ, Genistein が最も強い活性 があるとして見いだされた。

\section{$7 \cdot 2$ アロマターゼ阻害 ${ }^{17}$}

アロマターゼは男性ホルモンの testosterone および androstenedione から芳香族化反応を触媒し, estradiol および estrone を生成する酵素である。ヒト胎盤由来ア ロマターゼ活性はフラボン類により阻害され， 7, 8-benzoflavone, chrysin, apigenin, flavone, flavanone, quercetinの順で阻害活性は高い。

\section{8 最 後に}

植物エストロゲンに関して，2種の研究が今後必要で あると考える。その一つは内分泌晩乱作用の懸念である。 米国では幼児の大豆製品の攝取には注意が要するとの意 見がある。現在, 弱いエストロゲン作用を有する合成化 学物質だけが大きな問題として取り上げられているが, 今後，エストロゲン作用がやや強くかつ摄取量が圧倒的 に多い植物エストロゲンを含めた総合的な影響評価が重 要な研究課題となる。つまり, 現在の社会の関心がマス コミ等の影響でエストロゲン様活性が弱く且つ微量の合 成化合物に焦点を合わせ，ヒトが摄食する食品中の植物 由来のエストロゲン様化合物を評価していないことによ り, 内分泌擋乱問題の本質を見逃すことになる。第二は, 本稿で述べたように植物エストロゲンの骨粗鬆症治療, がん予防効果，コレステロール低下作用，心血管系への よい影響等の種々の薬理効果が期待されており，医療・ 医楽もしくは予防薬の観点から，今後ますます研究され ることと考える。イソフラボン類は今後, 閉経後の種々 の疾病の治療に，女性のホルモン補充療法としてますま す注目を集めると予測する。

(受付：1999 年 6 月 11 日，受理：1999 年 7 月 19 日)

\section{文献}

1) H.B. Patisaul, P.L. Whitten, "Endocrine Disruptors : Effects on male and female reproductive systems", ed by R.K. Naz, CRC Press, Boca Raton (1999), p.89.

2) R.J. Golden, K.L. Noller, L. T.-Ernstoff, R.H. Kaufman, R. Mittendorf, R. Stillman, E.A. Reese, CRC Crit. Rev. in Toxicol. 28, 109 (1998).

3) 山崎和男, ファルマシア, 35, 235, (1999).

4) 金子秀雄, 泩野文章, 松尾昌科, 科学（岩波書店） 68, 598 (1998)

5) 金子秀雄, 周産期医学，29，399-401 (1999).

6) 高井 泰, 廣井久彦, 堤 治, ホルモンと臨床 46 増刊号, 319 (1998).

7) 加藤茂明, 核内レセプターとシグナル伝達, 実験 医学，バイオサイエンス 19 (1994), p.45. 
8）小林良二, 萩原正敏, “レセプター一分子薬理学的 アプローチ”講談社サイエンティフィク (1997), p.77.

9) G.G.J.M. Kuiper, B. Carlsson, K. Grandien, E. Enmark, J. Häggblad, S. Nilsson, J-Å. Gustafsson, Endocrinology, 138, 863, (1997).

10) B.E. Gillesby, T.R. Zacharewski, Environ. Toxicol. Chem., 17, 3 (1998).

11) N.G. Coldham, M. Dave, S. Sivapathasundaram, D.P. McDonnell, C. Connor, M.J. Sauer, Environ. Health Perspect., 105, 734, (1997).

12）金子秀雄, 松永治之, 大江師久, 住田佳代, 未発
表データ.

13) R. Santti, S. Makela, L. Strauss, J. Korkman, M. Kostian, Toxicol. Ind. Health, 14, 223, (1997).

14) H. Adlercreutz, E. Hämäläinen, S. Gorbach, B. Goldin, Lancet, 339, 1233, (1992).

15) H. Adlercreutz, H. Markkanen, S. Watanabe, Lancet, 342, 1209, (1993).

16) T. Fotsis, M. Pepper, H. Adlercreutz, G. Fleischmann, T. Hase, R. Montesano, L. Schweigerer, Proc. Natl. Acad. Sci., 90, 2690, (1993).

17) J.T. Kelles, Jr., L.E. Vickery, Science, 225, 1032 , (1984). 


\title{
[総説］ リグナン類の機能性：特にゴマリグナンを中心に
}

\author{
大澤 俊 彦 \\ 名古屋大学大学院生命農学研究科 \\ （广 464-8601 愛知県名古屋市千種区不老町 1)
}

リグナン類は，広く植物界に存在し，様々な生理活性を持つ化合物である。油糧種子中では，特にゴマ種子中 に存在するユニークなゴマリグナン類が知られている。主要なリグナン類として，七サミン，七サモリンが知ら れていたが, ほとんどそれらの生理機能は明らかではなかった。そこで, セサミン，七サモリンをはじめ，七サ ミノールやピノレジノールなど脂溶性リグナン類が生体内で酸化ストレス予防効果を示すと共に, 多くの機能性 を有していることが明らかとなった。特に，セサミノールは強力にLDLの酸化を抑制し，ゴマ油の製造工程の みならず脱脂ゴマ粕からも摂取後, 腸内細菌によりセサミノール配糖体から二次的に生成することが明らかにさ れた。さらに，個体レベルにおける動脈硬化予防作用の検討のため，高コレステロール負荷ウサギと共に家族性 高脂血症のモデルであるワタナベラビット（WHHL）を対象に実験を行ったところ，有効に抑制し，今後の研究 の進展に期待が待たれる。

（連絡者：大澤俊彦） Vol.48, No.10，1041(1999)

\section{[総説］植物エストロゲンとその核内レセプター}

\section{金子秀雄}

住友化学工業株式会社生物環境科学研究所

（广 554-8558 大阪府大阪市此花区春日出中 3-1-98）

女性ホルモン様作用を有する植物エストロゲンは現在 200 種類が知られており，その中でもイソフラボン類の coumestrol, genistein および daidzein は強い活性を示す。これらのイソフラボン類は, エストロゲンレセプター に対して高い親和性を示す。イソフラボン類は, 内分泌攪乱作用で話題となっている合成化合物（例： bisphenol-A，4-nonylphenol）よりも強いエストロゲン作用（in vitro）を示し，また，日本人の場合は大豆製品 を通じて大量のイソフラボン類を捸取しているために内分泌攪乱作用が議論されている。一方，イソフラボン類 は骨粗箖症治療, 前立腺がん予防, 乳がん予防, コレステロール低下作用等の種々の薬効があると報告され, 植 物エストロゲン類のリスクバネフィトの両面をよりよく評価するために，さらなる分子レベルの研究の進展が 期待される。

(連絡者：金子秀雄） Vol.48, No.10, 1049 (1999)

\section{[総説］ テルペノイドの抗変異原性および抗発がん性}

\author{
宮 澤 三雄 \\ 近畿大学理工学部 \\ ( T 577-8502 大阪府東大阪市小若江 3-4-1)
}

本総説では各種テルペノイドの抗変異原性と抗発がん性について概説する。特に抗変異原性における試験法, 変異原物質およびその効果について取り上げた。本稿で扱った 87 種のテルペノイドの抗変異原性お゙よ゙抗発が ん性に関する報告は 1989-1999に報告されたものであり，それらの生理活性の特徴について紹介した。

(連絡者：宮澤三雄) Vol.48, No.10, 1057 (1999) 